\title{
Assortative Mating and Personality in Human Couples: A Study Using Cloninger's Temperament and Character Inventory
}

\author{
O. Le Bon ${ }^{1 *}$, M. Hansenne ${ }^{2}$, D. Amaru ${ }^{1}$, A. Albert ${ }^{3}$, M. Ansseau ${ }^{2}$, S. Dupont ${ }^{4}$ \\ ${ }^{1}$ CHU Tivoli, Department of Psychiatry, Université Libre de Bruxelles, Brussels, Belgium \\ ${ }^{2}$ Department of Psychiatry, Université de Liège, Liège, Belgium \\ ${ }^{3}$ Department of Biostatistics, Université de Liège, Liège, Belgium \\ ${ }^{4}$ The Sven Lovén Centre for Marine Sciences, Department of Biodiversity and Environmental Sciences, \\ University of Gothenburg, Kristineberg, Sweden \\ Email: "olebon@chu-tivoli.be
}

Received September $22^{\text {nd }}, 2012$; revised October $23^{\text {rd }}, 2012$; accepted November $21^{\text {st }}, 2012$

\begin{abstract}
The trend toward assortative mating is the rule in Western societies for a large series of factors. The case for personality variables is however not clear, since weak and even negative relationships have been found in correlation analyses between spouses. The present study compared the profiles of members from 145 stable couples living together for more than 5 years, and representative of the Belgian population. Personality measurements were performed using Cloninger's Temperament and Character Inventory (TCI), in order to: 1) determine whether the subject's TCI predicts the partner's profile; 2) determine whether modeling has an important influence between the partners; 3) describe the behavior of personalities with extreme traits; 4) measure whether personalities with extreme traits would favor complementarity over homogamy. In all dimensions but Harm Avoidance and its sub-dimensions, positive associations were found between the partners, indicating a trend toward assortative mating. These differences were significant for Novelty Seeking, Reward Dependence, Persistence and Cooperativeness. Trends were observed in Self-Directedness and Self-Transcendence. Subjects with extreme personality traits were not shown to favor complementarity over assortative mating. Homogamy was thus confirmed here for a series of personality traits, independently of the TCI Temperament or Character classification and on the subjects position in the distribution.
\end{abstract}

Keywords: Personality; TCI; Couples; Genetics; Assortative Mating

\section{Introduction}

As long as most of human reproduction remains sexual, the choice of the partner will be an essential issue, for it will determine the genetic apparatus of the offspring and the species. Although biology is unlikely to ever fully explain our eventual personal decisions, it may influence them considerably, if unconsciously. Natural selection-or in the present case, sexual selection, as Charles Darwin also put it-is of course at work, to ensure that only the fittest genes survive.

One robust constant in studies on mating is that, for almost every studied trait, the partners resemble each other (assortative mating) more than they would if couples were randomly assembled or if compensation for significant deviations from the mean (complementarity) was a priority. Assortative mating, also known as homogamy, has as such been demonstrated in a descending hierarchy in Western societies for factors as diverse as age, education, ethnic origin, religion, attitudes and opinions, intelligence (IQ), socioeconomic status, height, weight, eye color, number of siblings, or physical characteristics (see reviews by Vandenberg, 1972; Jensen, 1978; Thiessen \& Gregg, 1980; Merikangas, 1982; Bouchard \& McGue, 2003). Similarity between partners on psychological states or traits has also been linked to marital satisfaction (Antill, 1983; Kurdek, 1993; Luteijn, 1994; Murstein \& Williams, 1985; Richard et al., 1990; Russel \& Wells, 1991) and personal subjective well-being (Ar-

${ }^{*}$ Corresponding author. rindell \& Luteijn, 2000).

Preference for physically similar partners may help you decide who you talk to, social criteria may limit the circle within which you are able to make your choice, but personality is usually of primary importance to decide who you make children with, at least in our modern societies (Miller, 1997). Studies of couples evidenced significant similarities for major psychiatric disorders (Parnas, 1988; Maes et al., 1998; Galbaud du Fort et al., 1994) and antisocial behavior (Krueger et al., 1998; Galbaud du Fort, 2002), so that assortative mating can also be suspected here. The case of personality in the general population is less clear, as several studies using correlations between spouses reported negative findings, or very weak relationships (up to .20) (Richardson, 1939; Hill, 1973; Farley \& Davis, 1977; Farley \& Mueller, 1978; Buss, 1985). Others (McCrae et al., 2008; Escorial \& Martin-Buro, 2012) found positive, although moderate, correlations.

Personality has been estimated to be determined, from $50 \%$ to $66 \%$, by genetic factors (Loehlin \& Nichols, 1976; Pederson et al., 1988; Tellegen et al., 1988; Bouchard, 1994; Bouchard \& McGue, 2003). Genes coding for enzymes, transporters or receptors playing a key role in neurotransmission are likely to be involved in personality characteristics. Variations in their biological actions will contribute to the variations in their phenotypical expression. Complex behavioral dimensions will involve multiple biological underpinnings, each of which is determined by discrete genes. The hypothesis of a multiple- 
gene heredity on complex behavior suggests a continuum of genetic risk that extends from normal to abnormal behavior. Consequently, an important implication of a polygenic model is its dimensionality.

Cloninger (1986; 1987; Cloninger et al., 1993) has constructed his biosocial model on the basis of such assumptions. In contrast to other models which consider that personality is fully derived from biology (Eysenck \& Eysenck, 1969), or do not otherwise specify etiological factors (most of the others), the model divides personality in two categories: Temperament is postulated to reflect behavioral traits mainly shaped by genetical or neurophysiological elements, whereas Character includes behavioral traits primarily linked to learning. The Temperament dimensions include: 1) Novelty Seeking (NS), supposedly associated with dopaminergic activity, was defined as the tendency to respond actively to novel stimuli leading to the pursuit of rewards and escape from punishment; 2) Harm Avoidance (HA), linked to serotonergic activity, corresponds to the tendency toward an inhibitory response to signals of aversive stimuli leading to avoidance of punishment and non-reward; 3 ) Reward Dependence (RD), associated with noradrenergic activity, was defined as the tendency for a positive response to signals of reward to maintain or resist behavioral extinction; 4) Persistence (PE), originally included in the RD dimension, was later individualized and is not at present specifically linked to a neurotransmitter. The Character dimensions include: 5) SelfDirectedness (SD) referring to the ability of an individual to control, regulate and adapt his or her behavior to fit the situation in agreement with individually chosen goals and values; 6) Cooperativeness (CO) was formulated to account for individual differences in identification with and acceptance of other people. Cooperative individuals are described as socially tolerant, empathic, helpful and compassionate, whereas uncooperative individuals are described as socially intolerant, disinterested in other people, unhelpful and revengeful; 7) Self-transcendence (ST) is associated with spirituality and refers generally to identification with everything conceived as essential and consequential parts of a unified whole. Except for PE, all dimensions are divided into sub-dimensions (from three to five).

Independently performed correlations between the four temperament dimensions and biological or genetic elements (Novelty Seeking: Benjamin et al., 1996; Ebstein et al., 1996; Staner et al., 1998; Harm Avoidance: Ricketts et al., 1998; Mazzanti et al., 1998; Hansenne et al., 1999; RD: Ebstein et al., 1997; Garvey et al., 1996; Persistence: Benjamin et al., 2000; Comings et al., 2000) have added credit to Cloninger's hypotheses. However, not all replications could confirm the evidence (Herbst et al., 2000; Blairy et al., 2000; Samochowiec et al., 2001), so that the topic remains controversial.

The present study used the Temperament and Character Inventory (TCI), a well-validated 226-item binary self-questionnaire, developed to assess the seven dimensions of the model (Cloninger et al., 1994). It was used on a group of 145 couples living together for 5 years or more. This selection helped avoid confusion with less stable early mating. The objectives were: 1) to measure potential associations between partners for every dimension and sub-dimension of the TCI, using intraclass correlations; 2) to measure the potential modeling effect over time between members of a couple, by measuring the interaction between the duration of the relationship and the links between partners; 3) to describe the relationships of people with extreme traits; 4) to measure whether subjects with extreme traits "compensate" for these by mating with subjects showing opposite characteristics. For these latter analyses, real couples were compared with randomly - assigned heterosexual pairs from the same original sample.

\section{Material and Methods}

\section{Subjects}

Subject selection was in four steps: 1) The original sample was designed to be representative of the Belgian population with respect to sex, age, geographical area and educational level. It was used for a university survey conducted on a nearly annual basis since 1992, to evaluate a series of variables on the family life. It included 7015 subjects, of which 3901 (55\%) lived in the Flanders Region, 2458 (35\%) in the Wallonia Region, and $656(9 \%)$ in the Brussels Region; 2) Only Frenchspeaking subjects from the Wallonia and Brussels Regions $(\mathrm{n}=$ 3114) were eligible for the present study, in order to use only one version of the TCI on the sub-sample at step 3. Mean male age was 43.9 (SD: 17.2, range: 16 - 87) and mean female age was 45.8 (SD: 18.5; range: 16 - 95). Highest education levels were: high-school (21\%), high-school level trade school (1\%), high-school level artistic studies (15\%), post high-school technical $(24 \%)$, college/university $(38 \%)$. (NB: school is mandatory at some level in Belgium until age 18); 3) a second randomization selected 161 men and 161 women, married or informally living together, and was again stratified for age, geographical area and educational level. The subjects were informed by mail that a personality questionnaire would be added to the usual material of the inquiry. No subject refused the protocol. The questionnaires were mailed 15 days after the instructions. An interviewer went to the subjects' residences to collect the questionnaires and to check whether all questions were completed adequately; 4) those who formed stable couples for at least five years were eventually analyzed $(n=290)$.

\section{Methods}

The TCI was used in its French translation by Le Bon, Staner and Stefos, a retro-translated version recognized by the author. Details can be found in a control database (Hansenne et al., 2001). Cronbach's alpha for the French version was .562 (NS); .722 (HA); .545 (RD); .729 (SD); .530 (CO); .352 (ST). No figure can be provided for PE, which includes only one subdimension.

The protocol was approved by the ethical committee of the University of Liège Medical School and all subjects gave their informed consent.

\section{Statistics}

All dimensions and sub-dimensions were compatible with parametric analyses (QQ plot).

Comparisons between categorical variables were performed using chi-square. Comparisons between continuous variables were performed using Student's t-test for unpaired groups. To measure the relationship between the partners' personality profiles, a first series of analyses used the intraclass correlation between the TCI scores.

A second series of analyses aimed to measure the behavior of subjects with the lowest and highest scores. Here, the main measure was the absolute value of the differences $(\Delta)$ between 
partners for every dimension. In order to determine what would be expected by chance, the absolute $\Delta$ between selected extreme scorers (for every dimension) and randomly-selected partners of the other sex was first established. To compensate for the limited size of the sub-samples and obtain a distribution of the mean absolute $\Delta$ corresponding to random mating, the process was repeated a thousand times (bootstrap procedure) for all potential partners in the sample except the real one (145 $-1=144)$. This provided a reference average which was subsequently compared with the actual partners (one-sample t-test).

For the analyses on extreme scorers, the subjects from both sexes were pooled together and sorted hierarchically for every dimension. Then two sub-samples were formed for every dimension, one for the low scorers and one for the high scorers. About $10 \%$ subjects were selected in each case. Due to ceiling and floor effect of the scales, the samples do not correspond exactly to the desired $10 \%$ (14 - 15 subjects) and actual ranges are from 11 to 26 subjects.

\section{Results}

\section{Sample Description}

The final selection included 145 males and 145 females living together for more than 5 years. Compared with the sample at step 2 (French-speaking global sample), there was no significant difference in education level or geographical area. Female $(p=.021)$ and male $(p=.005)$ age was higher in the sub-sample (step 4). Mean male age was: 49.5; SD: 13.9; range 24 - 80; mean female age was: $47.7 ; 14.5 ; 21$ - 79. The mean duration of the relationship was: 23.5 (SD: 13.9; 5 - 57). Men's age at marriage (or when the couple considered forming a stable union) was 26.1 (SD: $6.4 ; 17$ - 60); women's age at marriage was: $24.2(6.3 ; 14-59)$; the age difference between the partners was $1.8(4.2 ; 0-16)$. No statistically significant difference was found for any dimension or sub-dimension between the sample eventually selected and the sample at step 3 (couples including those living together for less than 5 years).

\section{TCI Scales Intercorrelations}

The TCI scales were shown not to be perfectly independent between them, as would be optimal for personality determination (Table 1). The highest correlations were found between Harm Avoidance and Self-Directedness $(r=-.415)$, Reward Dependence and Cooperativeness $(\mathrm{r}=.561)$, and between Self-Directedness and Cooperativeness $(r=.419)$.

Table 1.

TCI scales: intercorrelations.

\begin{tabular}{lcccccc}
\hline & NST & HAT & RDT & PET & SDT & COT \\
\hline HAT & -.093 & & & & & \\
RDT & .141 & .204 & & & & \\
PET & -.253 & -.267 & -.103 & & & \\
SDT & -.107 & -.415 & .111 & -.058 & & \\
COT & .048 & -.014 & .561 & -.190 & .419 & \\
STT & .018 & -.032 & .157 & -.022 & .001 & .167 \\
\hline
\end{tabular}

Legend: Pearson product moment "r".

\section{Comparison between the Partners}

Table 2 shows the associations between the partners' profiles. Significant associations were found for the following

Table 2.

Intraclass correlations $(\mathrm{n}=145 \times 2)$.

\begin{tabular}{|c|c|c|c|}
\hline & & ICC $\mathrm{r}$ & $\operatorname{ICC} p$ \\
\hline \multicolumn{4}{|c|}{ Novelty seeking } \\
\hline NS1 & Exploratory excitability & .356 & .005 \\
\hline NS2 & Impulsiveness & .249 & .043 \\
\hline NS3 & Extravagance & .421 & .001 \\
\hline NS4 & Disorderliness & .046 & $\mathrm{~ns}$ \\
\hline \multirow[t]{2}{*}{ NST } & Total & .334 & .007 \\
\hline & Harm avoidance & & \\
\hline HA1 & Anticipatory worry & .254 & $\mathrm{~ns}$ \\
\hline HA2 & Fear of uncertain & .150 & ns \\
\hline HA3 & Shyness with strangers & .121 & $\mathrm{~ns}$ \\
\hline HA4 & Fatigability & -.192 & $\mathrm{~ns}$ \\
\hline \multirow[t]{2}{*}{ HAT } & Total & .052 & $\mathrm{~ns}$ \\
\hline & Reward dependence & & \\
\hline $\mathrm{RD} 1$ & Sentimentality & .274 & .027 \\
\hline RD3 & Attachment & .229 & .059 \\
\hline $\mathrm{RD} 4$ & Dependence & .410 & .001 \\
\hline \multirow[t]{2}{*}{ RDT } & Total & .350 & .005 \\
\hline & Persistence & & \\
\hline \multirow[t]{2}{*}{ PET } & Persistence & .252 & .041 \\
\hline & Self-directedness & & \\
\hline $\mathrm{SD} 1$ & Responsibility & .264 & .031 \\
\hline $\mathrm{SD} 2$ & Purposefulness & .156 & $\mathrm{~ns}$ \\
\hline SD3 & Resourcefulness & .101 & $\mathrm{~ns}$ \\
\hline $\mathrm{SD} 4$ & Self-acceptance & .350 & .005 \\
\hline SD5 & Congruent second nature & .308 & .014 \\
\hline \multirow[t]{2}{*}{ SDT } & Total & .226 & $(.062)$ \\
\hline & Cooperativeness & & \\
\hline $\mathrm{CO} 1$ & Social acceptance & .165 & $\mathrm{~ns}$ \\
\hline $\mathrm{CO} 2$ & Empathy & .110 & $\mathrm{~ns}$ \\
\hline $\mathrm{CO} 3$ & Helpfulness & .366 & .003 \\
\hline $\mathrm{CO} 4$ & Compassion & .452 & .001 \\
\hline $\mathrm{CO} 5$ & Principled & .501 & .001 \\
\hline \multirow[t]{2}{*}{ СОТ } & Total & .432 & .001 \\
\hline & Self-transcendence & & \\
\hline ST1 & Self-forgetfulness & .277 & .026 \\
\hline $\mathrm{ST} 2$ & Transpersonal identification & .564 & .001 \\
\hline ST3 & Spiritual acceptance & .178 & $\mathrm{~ns}$ \\
\hline STT & Total & .237 & $(.052)$ \\
\hline
\end{tabular}


dimensions: Novelty Seeking, Reward Dependence, Persistence and Cooperativeness. Trends were present for Self-Directedness and Self-Transcendence. Within the dimensions, some heterogeneity was found, with sub-dimensions showing high degrees of similarity between the partners and others showing quite low grades. All the significant correlations were positive and only the nonsignificant links for fatigability, a sub-dimension of HA, was negative.

\section{Links with Age}

The correlation between the partners' $\Delta \mathrm{s}$ for dimensions and duration of the relationship was significant only for STT (r $=.222, p=.011$ ); all other r's were below .096 and not significant. No significant correlations were observed between the partners' $\Delta s$ for dimensions and age difference (all Pearson's $r$ were below .155 and not significant).

\section{Comparisons between Extreme Real and Randomly-Assigned Couples}

The difference between the partners was then tested in subsamples including one higher or one lower scorer for each scale
(Tables 3 and 4). The difference between the partners was smaller in the real couples than in randomly-assigned couples in all cases except for high Harm Avoidance and low Reward Dependence. The difference was significant in Cooperation (both high and low), low Reward Dependence and showed a trend for Novelty Seeking (both high and low).

\section{Discussion}

\section{Main Results}

The main result of this study was that the partners showed positive associations between them on all dimensions except Harm Avoidance and its sub-divisions where the results were more mixed. These associations were significant for Novelty Seeking, Reward Dependence, Persistence, Cooperativeness and the combined value, and trends were observed in SelfDirectedness and Self-Transcendence. No significant negative association was found. This shows a clear predominance of assortative mating over complementarity, which is in agreement with most of the literature on mating.

Novelty seeking and similar concepts were already shown previously to be the most predictive personality variable for

Table 3.

Comparisons of couples' $\Delta$ in the upper decile.

\begin{tabular}{|c|c|c|c|c|c|c|c|c|c|}
\hline & $\begin{array}{c}\text { Real couples } \\
\text { (mean) }\end{array}$ & SD & $\begin{array}{l}\text { Random couples } \\
\text { (mean) }\end{array}$ & SD & N (real couples) & Inclusive threshold & Max & Real $<$ random & $p$ \\
\hline$\Delta \mathrm{NST}$ & 9.92 & 6.08 & 13.11 & .03 & 12 & 27 & 40 & $98 \%$ & .096 \\
\hline$\triangle \mathrm{HAT}$ & 16.0 & 6.99 & 14.23 & .07 & 10 & 30 & 35 & $21 \%$ & ns \\
\hline$\triangle \mathrm{RDT}$ & 6.92 & 3.90 & 8.25 & .03 & 13 & 21 & 24 & $91 \%$ & ns \\
\hline$\triangle \mathrm{PET}$ & 2.65 & 2.03 & 3.07 & .01 & 26 & 8 & 8 & $92 \%$ & ns \\
\hline$\Delta \mathrm{SDT}$ & 9.75 & 8.23 & 11.53 & .06 & 16 & 41 & 44 & $82 \%$ & ns \\
\hline$\Delta \mathrm{COT}$ & 6.00 & 4.43 & 8.29 & .05 & 17 & 40 & 42 & $92 \%$ & .049 \\
\hline$\Delta \mathrm{STT}$ & 1.21 & 6.22 & 13.05 & .07 & 14 & 24 & 33 & $47 \%$ & ns \\
\hline
\end{tabular}

Legend: real and random couples' $\Delta$ for each TCI dimension. Because of ceiling and floor effect and ordinal distribution of the test, it was not possible to select precisely the desired sample size for the comparison. A threshold was thus defined in each case, to include about $10 \%$ of the total. Extremes sample size, threshold and maximum for the scale are given in columns 6 - 8. Real > random: percentage of cases where real couple's difference was smaller than in randomly-assigned couples. $p$ : one-sample t-test using the mean of the difference between randomly-assigned couples as the reference point. Please note that SD are of a different order of magnitude: this is due to the bootstrap procedure used with the randomly-assigned couples.

Table 4.

Comparisons of couples' $\Delta$ in the lower decile.

\begin{tabular}{|c|c|c|c|c|c|c|c|c|c|}
\hline & $\begin{array}{l}\text { Real couples } \\
\text { (mean) }\end{array}$ & $\mathrm{SD}$ & $\begin{array}{c}\text { Random couples } \\
\text { (mean) }\end{array}$ & $\mathrm{SD}$ & $\mathrm{N}$ (real couples) & Inclusive threshold & Min & Real $<$ random & $p$ \\
\hline$\Delta \mathrm{NST}$ & 8.10 & 4.79 & 11.08 & .09 & 10 & 7 & 0 & $85 \%$ & .081 \\
\hline$\Delta \mathrm{HAT}$ & 14.00 & 6.13 & 14.35 & .07 & 16 & 4 & 0 & $55 \%$ & ns \\
\hline$\Delta \mathrm{RDT}$ & 1.42 & 4.40 & 9.08 & .04 & 12 & 7 & 0 & $14 \%$ & $\mathrm{~ns}$ \\
\hline$\Delta \mathrm{SDT}$ & 14.29 & 8.20 & 17.31 & .06 & 14 & 17 & 0 & $94 \%$ & ns \\
\hline$\Delta \mathrm{COT}$ & 12.42 & 6.47 & 16.63 & .05 & 12 & 20 & 0 & $99 \%$ & .046 \\
\hline$\Delta \mathrm{STT}$ & 8.56 & 7.04 & 9.52 & .07 & 16 & 5 & 0 & $47 \%$ & ns \\
\hline
\end{tabular}

Legend: same as Table 3, except for Min instead of Max for each scale. 
assortative mating (Farley \& Davis, 1977). Within the dimensions, and although the consistency of the questionnaire has been repeatedly demonstrated, especially on the Temperament side, an important degree of heterogeneity was found in the prediction for the partner's profile. Therefore the sub-dimensions may prove more useful than global dimensions to define which traits are crucial for mating.

In their questionnaire, Cloninger et al. (1993) make an important theoretical distinction between behavioral traits that would be mainly shaped by genetical or neurophysiological elements (Temperament) and others bound primarily to learning (Character). If assortative mating is encouraged by Evolution, we would expect traits determined biologically to have more selective value than learned ones. Yet, this distinction was not supported by the present results, as traits from Character dimensions seem at least as strongly associated with mating than those of Temperament (the combined value for Temperament dimensions was in fact even less predictive of homogamy than its counterpart). This may either mean that assortative mating is not especially linked to biologically-transmitted traits, and that Evolution is thus irrelevant to assortative mating for the present matter, or that the distinction between the two parts of the model by Cloninger et al. is excessive. The design of the present study cannot solve this issue. However, a clear distinction between personality traits determined by nature or nurture has not been demonstrated in the literature published so far. It is even hypothesized that all personality traits are inherited (Bouchard \& McGue, 2003), which rather supports the second option. In this case, both personality categories could be partly determined genetically and partly by learning.

A second result of this study is that no relationship was found between the magnitude of the difference between the partners (all TCI dimensions) and the duration of the relationship, except for a weak link with Self-Transcendence. This can be interpreted as a sign of stability of a subject's temperament and character over the years, and of a limited effect of modelling on each other. Also, no relationship was found between the magnitude of the TCI dimensions difference between the partners and the age difference between them. These elements are in agreement with most of the literature on the topic (see Introduction).

Four nonexclusive reasons pushing for assortative mating are usually considered: 1) the partners in a couple should be similar because of Trait Convergence over the course of the relationship; this has however been rejected by practically all studies (Zonderman et al., 1977; Mascie-Taylor et al., 1989; Caspi \& Herbener, 1993; Sutton, 1993; Feng \& Baker, 1994), except perhaps for food choice (Bove et al., 2003); 2) Social Homogamy (Price \& Vanderberg, 1980; Eaves et al., 1989; Neale \& Cardon, 1992) proposes that individuals mate assortively mostly for reasons of shared environmental and social background: acceptable partners within a given social context would already be phenotypically similar; 3) in Phenotypic Assortment (Heath \& Eaves, 1985; Cardon et al., 1991; Eaves et al., 1978; Jencks, 1972), subjects would prefer to mate with people who are like them for a series of phenotypic traits, but the precise reason why they would do so is not clarified; 4) in Genetic Similarity, Rushton et al. (1984) postulate that individuals have a natural tendency to seek out genetically similar individuals, either actively or through an unknown mechanism, in order to ensure a maximum diffusion of their genes: random mating makes $50 \%$ of the genetic apparatus to be transmitted to the offspring; with assortative mating, as similar genes are provided by the partner, the resemblance between parent and child can only increase (see Eckman et al. (2002) for a critical review). A discussion on the relative merits of these theories and the models that have been derived from them (see Rao et al., 1974; Eaves, 1979; Campbell, 1980; Eaves et al., 1999) would go beyond the scope of the present work.

Trait convergence, as a hypothetic mechanism to explain assortative mating, is thus not supported here. The design of the present study does not permit to support one or another of the three remaining hypotheses.

\section{Extreme Traits and Assortative Mating}

It could be hypothesized that atypical subjects function differently than mainstream ones and perhaps somehow seek to temper their personality with somebody who possesses less extreme traits (complementarity). In most cases, subjects could thus tend to mate like individuals - and protect the genes that they have in common-except where the emotional unwellbeing linked to a very large deviation from the mean would be too strong.

About $10 \%$ of the sample was used for each scale and at both tails for the comparisons of the extreme traits. In twelve of the fourteen tests, the difference was smaller in the real couples than in the randomly-assigned ones and in nine tests, it was the case for between $82 \%$ to $98 \%$ of the comparisons. The difference between real and random couples' $\Delta \mathrm{s}$ was significantly smaller in the case of Cooperation (both tails). It was also smaller in Persistence (low scorers) and in Novelty Seeking (both tails). Combined Values were not used here, because it would represent an average of extreme traits, which has probably little theoretical interest. The hypothesis that subjects with extreme traits would tend to compensate instead of reinforcing their traits through marriage was thus not confirmed here. This also does not favor the concept that subjects would be faced with a choice between someone mirroring or complementing them (Pediaditakis et al., 1998).

\section{Theoretical Considerations}

The mating type has potentially important consequences on the species. Assortative mating, for instance, will mechanically increase the frequency of genotypes (combinations of genes) producing extreme phenotypes and decrease the frequency of genotypes creating average phenotypes. If matings are not random, then one of the conditions for the stability of allelle distribution, known as the Hardy (1908) and Weinberg (1908) law of population genetics, is contradicted. Animal breeding has shown how easy it is to select individuals with specific physical and behavior characteristics that do not exist in the wild. Although the increase in genotypic variance resulting from positive assortative mating is small for many characteristics, it accumulates over time. And, as the number of extremes increases, it will be easier for someone at that extreme to mate someone with the same characteristics, so that a positive feed-back loop is established. Families would become more homogeneous for a series of desired traits but differences between families would increase.

Within the distribution of any given trait, assortative mating tends to increase variability, along with inbreeding and bal- 
anced polymorphism, against other factors tending to reduce it, such as unidirectional natural selection, imperfect genetic transmission or complementary matings. However, complementarity has never been demonstrated as a group behavior. The present study indicates that even the subjects at the tails of the distribution do not show it. Studies in larger groups will be needed to demonstrate the conditions in which it appears.

Assortative mating thus contributes to maintain a degree of variety in allele distribution within a given group, which may be useful to the species. Atypical personalities, who may suffer individually in adjusting to normal situations, may on the other hand be in a better position than average ones to cope with a variety of special situations (from viral infections to physical aggression to intellectual challenges). Individuals with a combination of extreme personality traits will be especially useful at times when the group faces novel or threatening environments, as it increases the likelihood that a few of its members will be able to adjust to extreme situations and either save the group or simply survive and reproduce themselves.

\section{TCI Consistency}

In most cases, weak or very weak links were evidenced between TCI scales. There was no strong link within the Temperament scales and only one within the Character scales (SelfDirectedness and Cooperativeness). There were, however, two strong links between Temperament and Character scales (Harm Avoidance and Self-Directedness; Reward Dependence and Cooperativeness). Factor independence of the questionnaire should thus still be optimized.

\section{Limitations}

It should be reminded that stable couples, with offsprings of their own, are only a part of human reproduction. Historically, human mating systems have used every way imaginable, from polygyny, to polyandry, to endogamy (favoring marriages with close genetic relatives), to exogamy (excluding marriages with close relatives), or hypergamy (women marrying upwards in the socioeconomic hierarchy). In our modern Western societies, a non-negligible number of children are conceived outside marriage or stable couples.

The absence of relationships between the magnitude of the difference between the partner and the age difference between them or the duration of their relationship may have been influenced by the exclusion of couples with a relationship shorter than 5 years. The absence of modelling found here is however in agreement with all the literature on the subject.

\section{Conclusion}

The general trend toward assortative mating is confirmed for personality variables in a representative sample of stable couples.

\section{REFERENCES}

Antill, J. K. (1983). Sex role complementarity versus similarity in married couples. Journal of Personality and Social Psychology, 45, 145155. doi:10.1037/0022-3514.45.1.145

Arrindell, W. A., \& Luteijn, F. (2000). Similarity between intimate partners for personality traits as related to individual levels of satisfaction with life. Personality and Individual Differences, 28, 629-637.
doi:10.1016/S0191-8869(99)00125-7

Benjamin, J., Li, L., Patterson, C., Greenberg, B. D., Murphy, D. L., \& Hamer, D. H. (1996). Population and familial association between the D4 dopamine receptor gene and measures of novelty seeking. Nature Genetics, 12, 81-84. doi:10.1038/ng0196-81

Benjamin, J., Osher, Y., Lichtenberg, P., Bachner-Melman, R., Gritsenko, I., Kotler, M., Belmaker, R. H., Valsky, V., Drendel, M., \& Ebstein, R. P. (2000). An interaction between the catechol O-methyltransferase and serotonin transporter promoter region polymorphisms contributes to tridimensional personality questionnaire persistence scores in normal subjects. Neuropsychobiology, 41, 48-53. doi:10.1159/000026632

Blairy, S., Massat, I., Staner, L., Le Bon, O., Van Gestel, S., Van Broeckhoven, C., Hilger, C., Hentges, F., Souery, D., \& Mendlewicz, J. (2000). 5-HT2a receptor polymorphism gene in bipolar disorder and harm avoidance personality trait. American Journal of Medical Genetics, 96, 360-364.

Bouchard, T. J. (1994). Genes, environment and personality. Science, 264, 1700-1701. doi:10.1126/science.8209250

Bouchard, T. J., \& McGue, M. (2003). Genetic and environmental influences on human psychological differences. Journal of Neurobiology, 54, 4-45. doi:10.1002/neu. 10160

Bove, C. F., Sobal, J., \& Rauschenbach, B. S. (2003). Food choices among newly married couples: Convergence, conflict, individualism and projects. Appetite, 40, 25-41.

doi:10.1016/S0195-6663(02)00147-2

Buss, D. M. (1985). Human mate selection. American Scientist, 73, $47-$ 51.

Campbell, R. B. (1980). Polymorphic equilibria with assortative mating and selection in subdivided populations. Theoretical Population Biology, 18, 94-111. doi:10.1016/0040-5809(80)90042-8

Cardon, L. R., Fulker, D. W., \& Jöreskog, K. G. (1991). A LISREL 8 model with constrained parameters for twin and adoptive families. Behavior Genetics, 21, 327-350. doi:10.1007/BF01065971

Caspi, A., \& Herbener, E. S. (1993). Marital assortment and phenotypic convergence: Longitudinal evidence. Social Biology, 40, 48-60.

Cloninger, C. R., Przybeck, T. R., Svrakic, D. M., \& Wetzel, R. D. (1994). The temperament and character inventory (TCI): A guide to its development and use. St-Louis, MO: Washington University.

Cloninger, C. R., Svrakic, D. M., \& Przybeck, T. R. (1993). A psychobiological model of temperament and character. Archives of General Psychiatry, 50, 975-990. doi: $10.1001 /$ archpsyc. 1993.01820240059008

Cloninger, C. R. (1987). A systematic method for clinical description and classification of personality variants. Archives of General Psychiatry, 44, 573-588. doi:10.1001/archpsyc.1987.01800180093014

Cloninger, C. R. (1986). A unified biosocial theory of personality and its role in the development of anxiety states. Psychiatric Developments, 3, 167-226.

Comings, D. E., Gade-Andavolu, R., Gonzalez, N., Wu, S., Muhleman, D., Blake, H., Mann, M. B., Dietz, G., Saucier, G., \& MacMurray, J. P. (2000). A multivariate analysis of 59 candidate genes in personality traits: The temperament and character inventory. Clinical Genetics, 58, 375-385. doi:10.1034/j.1399-0004.2000.580508.x

Eaves, L. J., Last, K. A., Young, P. A., \& Martin, N. G. (1978). Model-fitting approaches to the analysis of human behaviour. Heredity, 41, 249-320. doi:10.1038/hdy.1978.101

Eaves, L. J. (1979). The use of twins in the analysis of assortative mating. Heredity, 43, 399-409. doi:10.1038/hdy.1979.90

Eaves, L. J., Fulker, D. W., \& Heath, A. C. (1989). The effects of social homogamy and cultural inheritance on the covariances of twins and their parents: A LISREL model. Behavior Genetics, 19, 113-122. doi:10.1007/BF01065887

Eaves, L. J., Heath, A., Martin, N., Maes, H., Neale, M., Kendler, K., Kirk, K., \& Corey, L. (1999). Comparing the biological and cultural inheritance of personality and social attitudes in the Virginia 30,000 study of twins and their relatives. Twin Research, 2, 62-80. doi: 10.1375/136905299320565933

Ebstein, R. P., Novick, O., Umansky, R., Priel, B., Osher, Y., Blaine, D., Bennett, E. R., Nemanov, L., Katz, M., \& Belmaker, R. H. (1996). Dopamine D4 receptor (D4DR) exon III polymorphism associated 
with the human personality trait of Novelty Seeking. Nature Genetics, 12, 78-80. doi:10.1038/ng0196-78

Ebstein, R. P., Seqman, R., Benjamin, J., Osher, Y., Nemanov, L., \& Belmaker, R. H. (1997). RH5-HT2C (HTR2C) serotonin receptor gene polymorphism associated with the human personality trait of reward dependence: Interaction with dopamine D4 receptor (D4DR) and dopamine D3 receptor (D3DR) polymorphisms. American Journal of Medical Genetics, 74, 65-72.

Eckman, R. E., Williams, R., \& Nagoshi, C. (2002). Marital assortment for genetic similarity. Journal of Biosocial Science, 34, 511-523. doi: $10.1017 / \mathrm{S} 0021932002005114$

Escorial, S., \& Martin-Buro, C. (2012). The role of personality and intelligence in assortative mating. The Spanish Journal of Psychology, 15, 680-687

Eysenck, H. J., \& Eysenck, S. B. G. (1969). Personality structure and measurement. London: Routledge \& Kegan Paul.

Farley, F. H., \& Davis, S. A. (1977). Arousal, personality, and assortative mating in marriage. Journal of Sexual and Marital Therapy, 3, 122-127. doi:10.1080/00926237708402977

Farley, F. H., \& Mueller, C. B. (1978). Arousal, personality, and assortative mating in marriage. Generalizability and cross-cultural factors. Journal of Sexual and Marital Therapy, 4, 50-53 doi:10.1080/00926237808403004

Feng, D., \& Baker, L. (1994). Spouse similarity in attitudes, personality, and psychological well-being. Behavior Genetics, 24, 357-364. doi:10.1007/BF01067537

Jencks, C. (1972). Inequality: A reassessment of the effects of family and schooling in America. New York: Basic Books.

Galbaud du Fort, G., Boothroyd, L. J., Bland, R. C., Newman, S. C., \& Kakuma, R. (2002). Spouse similarity for antisocial behaviour in the general population. Psychological Medicine, 32, 1407-1416. doi:10.1017/S0033291702006530

Galbaud du Fort, G., Kovess, V., \& Boivin, J. F. (1994). Spouse similarity for psychological distress and well-being: A population study. Psychological Medicine, 24, 431-447. doi:10.1017/S0033291700027409

Garvey, M. J., Noyes Jr., R., Cook, B., \& Blum, N. (1996). Preliminary confirmation of the proposed link between reward-dependence traits and norepinephrine. Psychiatry Research, 65, 61-64.

Hansenne, M., \& Ansseau, M. (1999). Harm avoidance and serotonin. Biological Psychology, 51, 77-81. doi:10.1016/S0301-0511(99)00018-6

Hansenne, M., Le Bon, O., Gauthier, A., \& Ansseau, M. (2001). Belgian normative data of the temperament and character inventory. European Journal of Psychological Assessment, 17, 56-62. doi:10.1027//1015-5759.17.1.56

Hardy, G. H. (1908). Mendelian proportions in a mixed population. Science, 28, 49-50. doi:10.1126/science.28.706.49

Heath, A. C., \& Eaves, L. J. (1985). Resolving the effects of phenotype and social background on mate selection. Behavior Genetics, 15, 1530. doi:10.1007/BF01071929

Herbst, J. H., Zonderman, A. B., McCrae, R. R., \& Costa Jr., P. T. (2000). Do the dimensions of the temperament and character inventory map a simple genetic architecture? Evidence from molecular genetics and factor analysis. American Journal of Psychiatry, 157, 1285-1290. doi:10.1176/appi.ajp.157.8.1285

Hill, M. S. (1973). Hereditary influence on the normal personality using the MMPI: II. Prospective assortative mating. Behavioral Genetics, 3, 225-232. doi:10.1007/BF01067599

Jensen, A. R. (1978). Genetic and behavioral effects on nonrandom mating. In R. T. Osborne, C. E. Noble, \& N. J. Wey (Eds.), Human variation: Biopsychology of age, race and sex. Waltham: Academic Press.

Krueger, R. F., Moffitt, T. E., Caspi, A., Bleske, A., \& Silva, P. A. (1998). Assortative mating for antisocial behavior: Developmental and methodological implications. Behavioral Genetics, 28, 173-186. doi:10.1023/A:1021419013124

Kurdek, L. A. (1993). Predicting marital dissolution: A 5-year prospective longitudinal study of newlywed couples. Journal of Personality and Social Psychology, 64, 221-242. doi:10.1037/0022-3514.64.2.221
Le Bon, O., Staner, L., Tecco, J., Pull, C., \& Pelc, I. (1998). Le questionnaire tridimensionnel de la personnalité (TPQ): Validation dans une population francophone \{Tridimensional Personality Questionnaire (TPQ): Validation in a French-speaking control population\}. L'Encéphale, 14, 40-45.

Loehlin, J. C., \& Nichols, R. C. (1976). Heredity, environment and personality. Austin, TX: University of Texas Press.

Luteijn, F. (1994). Personality and the quality of an intimate relationship. European Journal of Psychological Assessment, 10, 220-223.

Maes, H. H., Neale, M. C., Kendler, K. S., Hewitt, J. K., Silberg, J. L., Foley, D. L., Meyer, J. M., Rutter, M., Simonoff, E., Pickles, A., \& Eaves, L. J. (1998). Assortative mating for major psychiatric diagnoses in two population-based samples. Psychological Medicine, 28, 1389-1401. doi:10.1017/S0033291798007326

Mascie-Taylor, C. G. (1989). Spouse similarity for IQ and personality and convergence. Behavioral Genetics, 19, 223-227. doi:10.1007/BF01065906

Mazzanti, C. M., Lappalainen, J., Long, J. C., Bengel, D,. Naukkarinen, H., Eggert, M., Virkkunen, M., Linnoila, M., \& Goldman, D. (1998). Role of the serotonin transporter promoter polymorphism in anxietyrelated traits. Archives of General Psychiatry, 55, 936-940. doi:10.1001/archpsyc.55.10.936

McCrae, R. R., Costa, P. T., Martin, T. A., Oryol, V. E., Ruvishnikov, A. A., \& Senin, I. G. (2008). Personality trait similarity between spouses in four cultures. Journal of Research on Personality, 76, 1137-1163

Merikangas, K. R. (1982). Assortative mating for psychiatric disorders and psychological traits. Archives of General Psychiatry, 39, 1173 1180. doi:10.1001/archpsyc.1982.04290100043007

Miller, G. F. (1997). Mate choice: From sexual cues to cognitive adaptations. Ciba Foundation Symposium, 208, 74-87.

Murstein, B. I., \& Williams, P. D. (1985). Assortative matching for sex-role and marriage adjustment. Personality and Individual Differences, 6, 195-201. doi:10.1016/0191-8869(85)90109-6

Neale, M. C., \& Cardon, L. R. (1992). Methodology for genetic studies of twins and families. Doordrecht: Kluwer Academic Publishers.

Nunnally, J., \& Bernstein, I. H. (1994). Psychometric theory (3rd ed.). New York: McGraw-Hill.

Parnas, J. (1988). Assortative mating in schizophrenia: Results from the Copenhagen high-risk study. Psychiatry, 51, 58-64.

Pederson, N. L., Plomin, R., McClearn, G. E., \& Friberg, L. (1988) Neuroticism, extraversion and related traits in adult twins reared apart and reared together. Journal of Personality and Social Psychology, 55, 950-957. doi:10.1037/0022-3514.55.6.950

Pediaditakis, N. (1998). Factors and their origins in mate selection and choice among humans: Implications for individual psychotherapy and counseling. Medical Hypotheses, 51, 359-366. doi:10.1016/S0306-9877(98)90029-9

Price, R. A., \& Vandenberg, S. G. (1980). Spouse similarity in American and Swedish couples. Behavior Genetics, 10, 59-71. doi:10.1007/BF01067319

Rao, D. C., Morton, N. E., \& Yee, S. (1974). Analysis of family resemblance II. A linear model for familial correlation. American Journal of Human Genetics, 26, 331-359

Richard, L. S., Wakefield, J. A., \& Lewak, R. (1990). Similarity of personality variables as predictors of marital satisfaction: A Minnesota Multiphasic Personality Inventory (MMPI) item analysis. Personality and Individual Differences, 11, 39-43. doi:10.1016/0191-8869(90)90166-O

Richardson, H. M. (1939). Studies of mental resemblance between husbands and wives and between friends. Psychological Bulletin, 36, 104-120. doi: $10.1037 / \mathrm{h} 0063390$

Ricketts, M. H., Hamer, R. M., Sage, J. I., Manowitz, P., Feng, F., \& Menza, M. A. (1998). Association of a serotonin transporter gene promoter polymorphism with harm avoidance behaviour in an elderly population. Psychiatric Genetics, 8, 41-44. doi:10.1097/00041444-199800820-00001

Rushton, J. P., Russell, R. J. H., \& Wells, P. A. (1984). Genetic similarity theory: Beyond kin selection. Behavior Genetics, 14, 179-193. doi:10.1007/BF01065540

Russel, R. J. H., \& Wells, P. A. (1991). Personality similarity and qual- 
ity of marriage. Personality and Individual Differences, 12, 407-412. doi:10.1016/0191-8869(91)90057-I

Samochowiec, J., Rybakowski, F., Czerski, P., Zakrzewska, M., Stepien, G., Pelka-Wysiecka, J., Horodnicki, J., Rybakowski, J. K., \& Hauser, J. (2001). Polymorphisms in the dopamine, serotonin, and norepinephrine transporter genes and their relationship to temperamental dimensions measured by the Temperament and Character Inventory in healthy volunteers. Neuropsychobiology, 43, 248-253. doi: $10.1159 / 000054898$

Staner, L., Hilger, C., Hentges, F., Monreal, J., Hoffmann, A., Couturier, M., Le Bon, O., Stefos, G., Souery, D., \& Mendlewicz, J. (1998). Association between novelty-seeking and the dopamine D3 receptor gene in bipolar patients: A preliminary report. American Journal of Medical Genetics, 81, 192-194.

Sutton, G. C. (1993). Do men grow to resemble their wives, or viceversa? Journal of Biosocial Science, 25, 25-29.

doi:10.1017/S0021932000020253
Tellegen, A., Lykken, D. T., Bouchard, T. J., Wilcox, K., Segal, N., \& Rich, A. (1988). Personality similarity in twins reared together and apart. Journal of Personality and Social Psychology, 54, 1031-1039. doi:10.1037/0022-3514.54.6.1031

Thiessen, D. D., \& Gregg, B. (1980). Human assortative mating and genetic equilibrium: An evolutionary perspective. Ethology and Sociobiology, 1, 111-140. doi:10.1016/0162-3095(80)90003-5

Vandenberg, S. G. (1972). Assortative mating, or marries whom? Behavioral Genetics, 2, 127-158. doi:10.1007/BF01065686

Weinberg, W. (1908). Über den Nachweis der Vererbung beim Menchen. Jahresh. Verein f. vaterl. Naturk in Wruttemberg, 64, 368382.

Zonderman, A. B., Vandenberg, S. G., Spuhler, K. P., \& Fain, P. R. (1977). Assortative marriage for cognitive abilities. Behavior Genetics, 7, 261-271. doi:10.1007/BF01066279 